\title{
Role of Leptin in Japanese Quail Development
}

\author{
M. MÁČAJOVÁ ${ }^{1}$, D. LAMOŠOVÁ ${ }^{1}$, M. ZEMAN ${ }^{1,2}$ \\ ${ }^{1}$ Institute of Animal Biochemistry and Genetics, Slovak Academy of Sciences, Ivanka pri Dunaji, Slovakia \\ ${ }^{2}$ Department of Animal Physiology and Ethology, Comenius University, Bratislava, Slovakia \\ Received July 11, 2002 \\ Accepted November18, 2002 \\ Abstract \\ Máčajová M., D. Lamošová, M. Zeman: Role of Leptin in Japanese Quail Development. \\ Acta Vet Brno 2002, 71: 473-479. \\ Leptin, a hormone produced mainly by adipose tissue, controls energy balance and can also \\ influence the embryonic development and growth. In our study we investigated the effects of leptin \\ administration during the embryonic development on hatching rate, posthatching growth and \\ development of Japanese quail (Coturnix japonica). At embryonic day $5,0.1 \mu \mathrm{g}$ or $1 \mu \mathrm{g}$ of \\ recombinant mice leptin in $50 \mu \mathrm{l}$ of phosphate buffered saline was injected into the albumen of \\ incubating eggs. Birds from each group were weighed daily and killed by decapitation at day 0,2 , \\ $5,7,14,21,28,35,42,49$ and 56 of postembryonic life. Plasma concentrations of triiodothyronine \\ (T3), testosterone and total lipids in plasma and in the liver were measured. Quail treated with leptin \\ hatched earlier and expressed a higher body weight during the whole experimental period than the \\ control group $(p<0.05)$. Significant changes in T3 concentrations, total lipids and body weight \\ were seen immediately after hatching and shortly before sexual maturity. Testosterone levels and \\ eggs laying were higher in leptin groups in comparison to controls. We suppose that the endocrine \\ milieu of the developing avian embryo is influenced by leptin and the administration of this \\ hormone during embryonic life can accelerate embryonic development of birds. \\ birds, embryogenesis, growth, reproduction, triiodothyronine, testosterone, total lipids
}

Leptin plays an important role as a signal of the body fat content to the brain, where it regulates food intake and energy expenditure (Friedman and Halaas 1998). It is important not only for the control of food intake and energy balance, but it functions also as a metabolic and neuroendocrine hormone. Leptin has been implicated as a mediator of diverse physiological features, including reproduction, growth, hematopoiesis, renal function, immune functions and angiogenesis (Ahima et al. 1996). Surprisingly, it is synthesized at a high rate in the placenta and may function as a growth factor for the fetus, signaling the nutritional status from the mother to her fetus (Masuzaki et al. 1997). This hormone is a growth factor for many cell types, including lymphocytes (Lord et al. 1998), cultured tracheal epithelial cells, lung squamous cells (Tsuchiy a et al. 1999), pancreatic (Tan abe et al. 1997) and embryonic cells. Moreover, leptin seems to have a key role in the regulation of the reproductive system, at both peripheral and central levels. There are also known interactions between leptin and sex hormones: for example, it is known, that leptin stimulates GnRH, FSH and LH release (Yu et al. 1997).

Chicken leptin mRNA appears to be most abundant in the liver, which is the major site of fat synthesis in birds. The presence of leptin mRNA in the liver suggests that birds may have a different mechanism for regulating food intake and energy expenditure than mammals (Ashwell et al. 1999). Leptin expression was also detected in the chick embryonic liver and yolk sac (A s hwell et al. 1999), suggesting that leptin may have a role in the chick embryo similar to that hypothesized for leptin in the placenta of mammals. In the developing embryo, leptin expression is detectable as early as 72 hours of incubation (McMurtry et al. 2000).

Address for correspondence:

Mgr. Mariana Máčajová

Institute of animal Biochemistry and Genetics, SASci,

90028 Ivanka pri Dunaji, Slovakia
Phone: $+421-2-45943232$

E-mil: marian

Entt//www.vfu.cz/acta-vet/asaavba.sk 
It has been found that recombinant murine leptin has a stimulatory effect on the proliferation of cultured embryonic chicken muscle and liver cells (Lamošová and Zeman 2001). Therefore, the purpose of this study was to determine if recombinant murine leptin injected into hatching eggs of Japanese quail during the embryonic period acts as a growth factor and subsequently influences postembryonic growth, food intake and sexual development.

\section{Materials and Methods}

Eggs of Japanese quail from our breeding colony were divided into three groups (93 in each group). The average weight of eggs in every group was equalized before the experiment $(9.20 \pm 0.25 \mathrm{~g})$. Eggs were incubated in a forced draught incubator with automatic turning every two hours at $37.5 \pm 0.2{ }^{\circ} \mathrm{C}$ and $50-60 \%$ relative humidity. At embryonic day 5 recombinant murine leptin (Pepro Tech, EC, England) in $50 \mu 1$ of phosphate buffered saline (PBS) was injected into the albumen of eggs. Two different concentrations of leptin were used: $0.1 \mu \mathrm{g}(\mathrm{L} 1)$ and $1 \mu \mathrm{g}$ (L2). The control group (C) was injected with $50 \mu 1$ of PBS. After hatching each group of birds was kept in a separate box up to day 35 of postembryonic life (PD 35), after which the animals were placed in individual cages. Continuous lighting at intensity 60- 80 lux was imposed. Quail were fed ad libitum with feeding mash (21\% crude protein and $12 \mathrm{MJ} / \mathrm{kg}$ of metabolizable energy). Individual body weight and food intake (per group to PD 35 and then individually) were recorded daily. Six animals from each group were decapitated at PD 0, 2, 5., 7, 14, 21, 28 , $35,42,49,56$. Blood samples were collected into heparinized tubes and then centrifuged. Plasma was stored at $-20{ }^{\circ} \mathrm{C}$ until assayed for testosterone (RIA, Immunotech, Slovakia), T3 (RIA, Immunotech, Slovakia) and total lipids in plasma (Bio-la-test, Lachema, Czech Republic). Liver was weighted and taken for determination of the total lipids (Bio-la-test, Lachema, Czech Republic).

Data are presented as means \pm S.E.M. The results were analysed by two-way analysis of variance (ANOVA) and Student's $t$-test.

\section{Results}

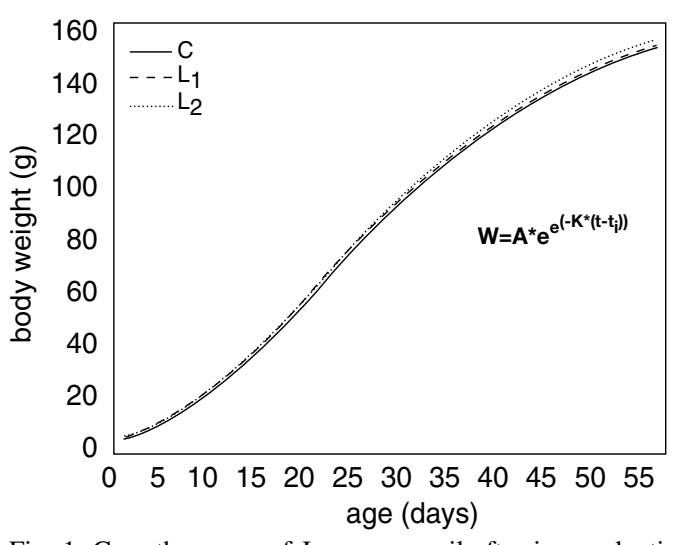

Fig. 1. Growth curves of Japanese quail after in ovo leptin administration on day 5 of incubation. Body weight data were fitted by Gompertz function: $\mathrm{W}=\mathrm{A} * \mathrm{e}^{\left(-\mathrm{K}^{*}\left(\mathrm{t}-\mathrm{t}_{\mathrm{i}}\right)\right)}$, where $\mathrm{A}$ is the asymptotic size, $\mathrm{K}$ the rate constant of the equation and ti is the inflection point of the growth curve (Starck and Ricklefs, 1998). Solid lines - control group, dashed lines - L1 group $(0.1 \mu \mathrm{g}$ of leptin) and dotted lines - L 2 group $(1,0 \mu \mathrm{g}$ of leptin).
In all trials quail from groups treated with leptin during the embryonic period hatched earlier (about $5-24 \mathrm{~h}$ ) than the control group. Leptin injected into eggs did not evoke developmental malformations in quail and did not change the gross weight of internal organs. The hatchability was similar in all groups (C: $71.2 \%$; L1: 69.5\%; L2: $73.6 \%)$. The mean body weights of hatched quail were as follows: $\mathrm{C}$ group: $6.23 \pm 0.07 \mathrm{~g}$; L1 group: $6.69 \pm 0.07 \mathrm{~g}$ ( $p<0.001$ vs. C) and L2 group: 6.46 $\pm 0.07 \mathrm{~g}(p<0.05$ vs. C).

There was a significant effect of treatment $(F 2,2960=16.6, p<0.001)$ on body weight. Mean body weights across the whole observation period were higher in birds from both groups treated with leptin compared to those in the control group $(p<0.05)$ (Fig. 1).

T3 levels were significantly lower in L1 and L2 groups $(p<0.05)$ on the day of hatching in comparison with the control (C: $7.44 \pm 1.28 \mathrm{nmol} / 1 ; \mathrm{L} 1: 4.86 \pm 0.23 \mathrm{nmol} / 1 ; \mathrm{L} 2: 4.26 \pm 0.08$ $\mathrm{nmol} / \mathrm{l})$. In the following days, the concentrations of plasma T3 in treated quail did not differ from control levels.

The highest food intake was observed in the group treated with the lower leptin concentration (L1), but the differences between groups were not significant. The highest 
daily body weight gain up to somatic maturity, was also recorded in the L1 group. The feed efficiency was approximately equal in all three groups (Table 1).

Table 1

The feed consumption converted to body weight gain $(\mathrm{g} / \mathrm{g})$ per one quail from day 5 till day 56 of life. $\mathrm{C}-$ control group; $\mathrm{L} 1-0.1 \mu \mathrm{g}$ of leptin ; L2 - $1 \mu \mathrm{g}$ of leptin.

\begin{tabular}{|c|c|c|c|c|c|c|c|c|c|}
\hline Age (days) & 5 & 7 & 14 & 21 & 28 & 35 & 42 & 49 & 56 \\
\hline C & 2.03 & 2.13 & 2.33 & 2.75 & 3.59 & 6.50 & 4.80 & 10.87 & 12.50 \\
\hline L1 & 1.98 & 2.24 & 2.41 & 2.76 & 3.85 & 6.53 & 5.09 & 12.30 & 10.80 \\
\hline L2 & 2.36 & 1.99 & 2.34 & 2.79 & 3.69 & 6.26 & 4.12 & 10.25 & 11.40 \\
\hline
\end{tabular}

Liver weights from all groups did not differ during the period of intensive growth, but was higher in the L1 group during the egg laying period (Fig. 2A). The standard developmental pattern of total lipids in the liver exhibited higher values after hatching, decreased levels during the rapid growth phase and the expected increase afterwards, which paralleled egg laying rate (Fig. 2B). A significant decrease in total lipids in plasma was found on the day of hatching in both leptin groups. Later, during the period of intensive growth and before sexual maturity, the differences among the groups were not significant (Fig. 2C).

Some differences in traits associated with sexual maturity were found. Males treated with leptin showed a trend toward higher testicular weights from PD 35 onwards (Tab. 2). Testosterone levels were significantly higher in L1 group $(p<0.05)$ at PD 49 in comparison with controls (C: $1.79 \pm 0.27 \mu \mathrm{g} / \mathrm{ml} ; \mathrm{L} 1: 3.36 \pm 0.47 \mu \mathrm{g} / \mathrm{ml} ; \mathrm{L} 2: 4.08 \pm 1.30 \mu \mathrm{g} / \mathrm{ml})$.

Table 2

Weight of testes (g) of Japanese quail after in ovo leptin administration on day 5 of incubation. C-control group; L1 - $0.1 \mu \mathrm{g}$ of leptin; L2 $-1 \mu \mathrm{g}$ of leptin. Data are means from six animals \pm S.E.M.

\begin{tabular}{|c|c|c|c|c|c|}
\hline day of life & 21 & 28 & 35 & 42 & 49 \\
\hline C & $0.08 \pm 0.01$ & $0.36 \pm 0.07$ & $1.03 \pm 0.20$ & $2.49 \pm 0.05$ & $3.74 \pm 0.04$ \\
\hline L1 & $0.05 \pm 0.02$ & $0.39 \pm 0.05$ & $1.41 \pm 0.37$ & $2.65 \pm 0.45$ & $3.96 \pm 0.02$ \\
\hline L2 & $0.04 \pm 0.02$ & $0.30 \pm 0.08$ & $1.35 \pm 0.14$ & $2.82 \pm 0.24$ & $3.93 \pm 0.02$ \\
\hline
\end{tabular}

An earlier onset of egg laying was observed in females treated with $0.1 \mu \mathrm{g}$ of leptin $\left(\mathrm{L}_{1}-2\right.$ days) compared with the control group. Females from leptin groups reached $100 \%$ eggs laying earlier than the control group. The production of total egg mass (total weight of eggs) per one quail and the egg laying rate were higher in both leptin groups (Fig. 3A,B). The highest average production of egg mass per quail and per day was in the $\mathrm{L}_{1}$ group $(6.15 \mathrm{~g}$, in $\mathrm{L}_{2} 6.01 \mathrm{~g}$, and in the control group $5.43 \mathrm{~g}$ ).

\section{Discussion}

Leptin gene homologues have been cloned in several species. The leptin homology among avian and mammalian species is a subject of discussion (Ta ouis et al. 1998; FriedmanEinat 1999), but recent phylogenetic analysis shows that the mouse leptin gene sequence has a higher similarity with the chicken sequence than with those of other mammals (D oy on et al. 2001). Because of the close similarity in the primary structures of the mammalian and avian leptin, and because it has been found that chick embryonic muscle cells and hepatocytes are sensitive to mouse leptin (Lamošová and Zeman 2001), we used commercially available recombinant murine leptin in our experiments.

Leptin probably plays an important role in embryonic development, as evidenced by production of leptin in placenta and widespread expression of leptin and its receptors in 

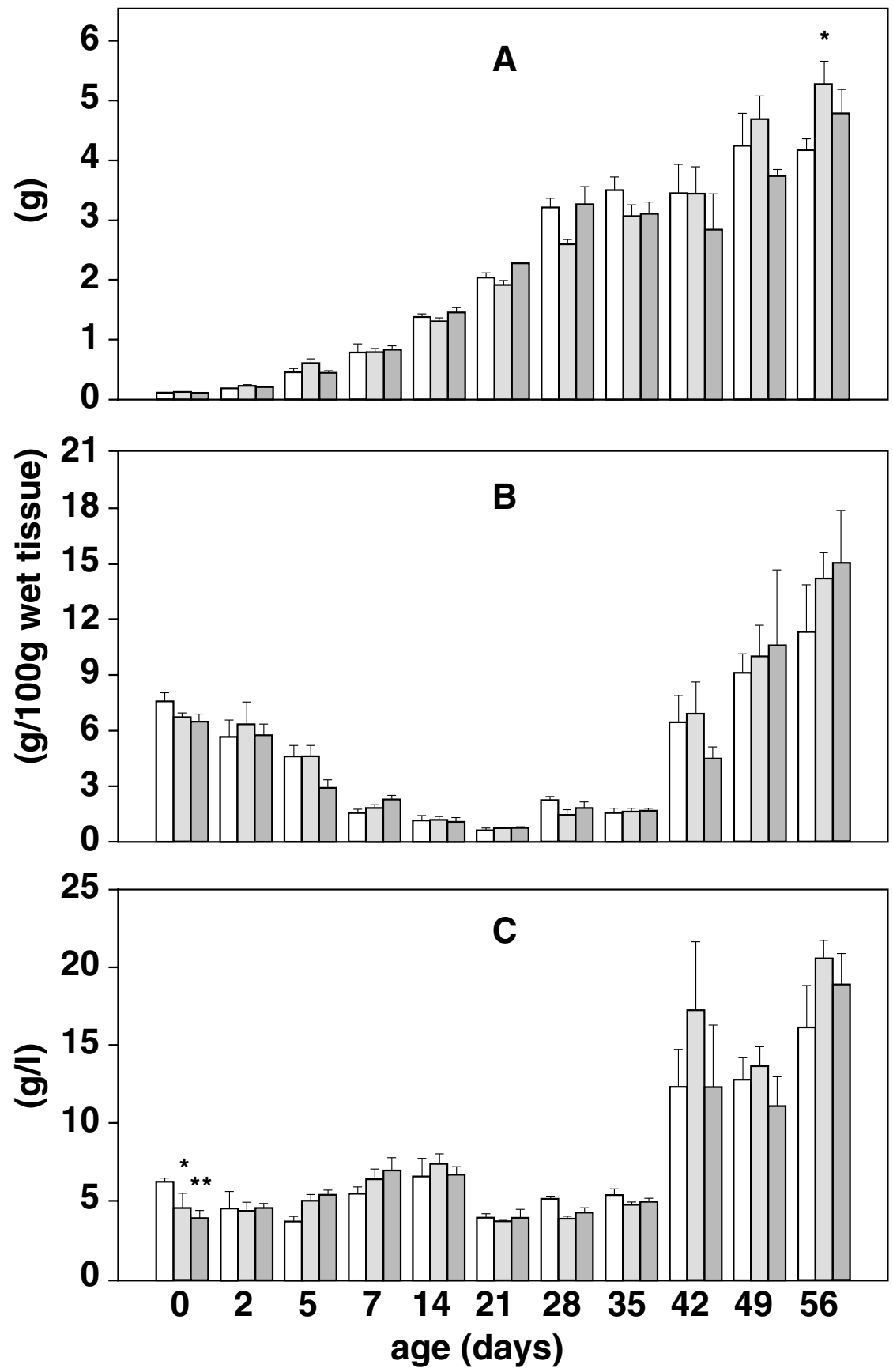

Fig. 2: A- Liver weights, B- amount of total lipids in liver and C- concentrations of total lipids in plasma of Japanese quail after in ovo leptin administration on day 5 of incubation. Open columns designate the control group, left hatched columns $\mathrm{L}_{1}$ and shaded columns $\mathrm{L}_{2}$ group. $* P<0.05$; $* * P<0.01$ vs. control. Data are means from six animals \pm S.E.M. 

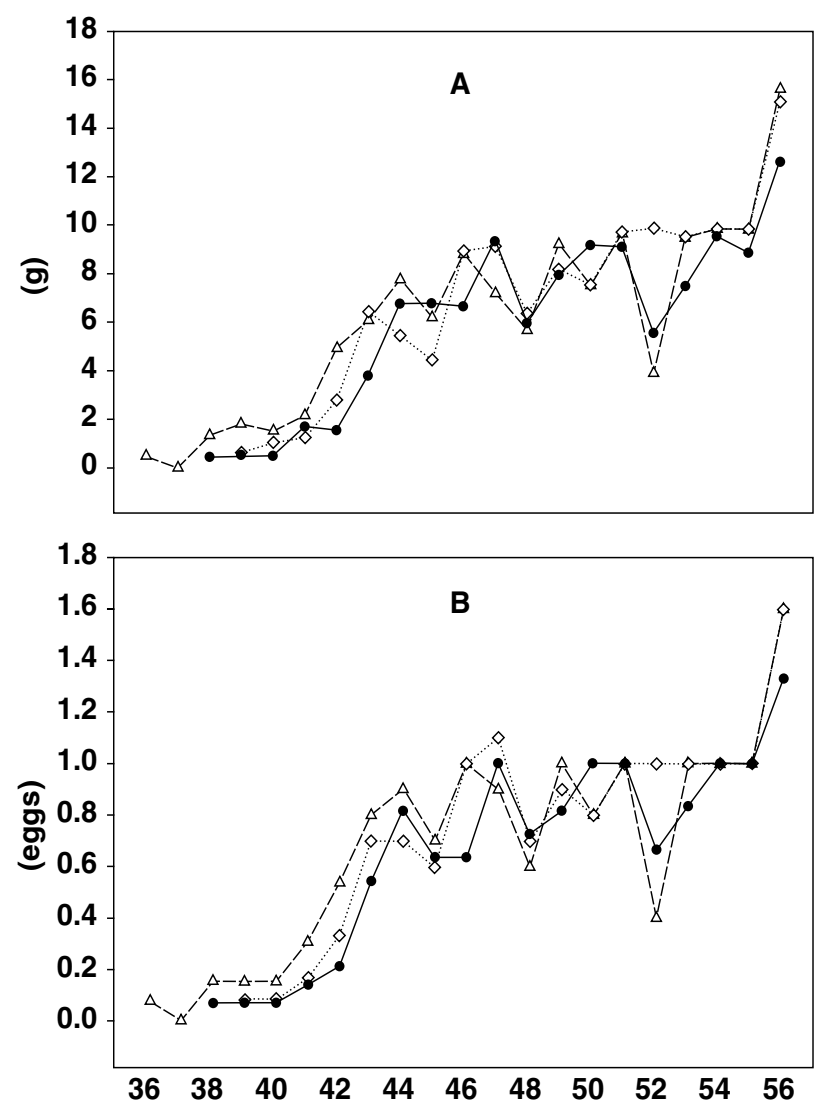

Fig. 3: A- Production of total egg mass and B- rate of egg production by one quail after in ovo leptin administration on day 5 of incubation. The legend is the same as in Fig. 1. Data are means from 6-8 animals. mammalian fetal tissue (Masuzaki et al. 1997). It has been hypothesized that leptin may play a physiological role in the implantation of fertilized eggs and in the subsequent early embryonic development (Gonzalez 2000). The avian embryo, which develops in isolation and is not maternally influenced, seems to be an appropriate model for studying the developmental processes induced by leptin in higher vertebrates. The presence of leptin mRNA was demonstrated in the brain, bursa Fabricii, heart, liver, muscle, and spleen of 5-day-old Leghorn embryo (Ashwell et al. 1999). Moreover, leptin expression was detectable as early as 72 hours in the developing chick embryo (McMurtry et al. 2000). Presence of leptin mRNA in the developing chick embryo, similar to rodent embryos (Hoggard et al. 1997) suggests that leptin has paracrine and endocrine effects on embryogenesis. Leptin expression in the embryonic yolk sac implicates that this hormone may control energy expenditure by mediating nutrient transfer to the developing embryo. Our data suggest that administration of leptin into quail eggs at ED 5 may affect the developing neuro-endocrine axis. In all our experiments quail from groups treated with leptin hatched significantly earlier than those from the control group, and their body weights were higher throughout the whole time period in which we observed them. This means that the higher leptin levels during embryonic development caused the faster development of the embryo.

It is known, that concentrations of serum T3 in Japanese quail are highest during internal pipping and then decrease abruptly to the day of hatching ( $\mathrm{McNabb}$ 1987). In our experiments we measured significantly lower concentration of T3 in leptin treated groups in comparison to controls at the day of hatching ( $<24 \mathrm{~h}$ old). This fact corresponds with the earlier hatching of quail from leptin treated groups.

It has been proposed that leptin is one of the signals controlling sexual maturation and is involved in the regulation of reproductive functions (Reitman et al. 2001). Administration of leptin to infertile $o b / o b$ (leptin deficient) mice stimulates all aspects of their reproductive endocrine system and rescues their fertility (Barash et al. 1996; Chehab et al. 1997). Injection of leptin accelerates sexual maturation in normal weanling mice as well as the 
timing of the first litter (A hima et al. 1997). These data suggest that this hormone functions as a trophic factor for the reproductive system in mammals, but there are still very limited data in birds. In our experiments quail females from both leptin treated groups reached sexual maturity earlier than controls (evaluated by the first laid egg and reaching $100 \%$ of egg laying). We hypothesize that the higher leptin levels during embryonic development evoked permanent changes in the neuroendocrine system controlling reproductive processes and consequently inducing earlier sexual maturity (higher concentration of testosterone in males and earlier onset of egg laying in females). Higher concentrations of lipids in the liver and higher weights of the liver in the leptin groups are also probably connected with the earlier onset of egg laying.

In summary, our results suggest that murine recombinant leptin administered during the embryonic period acts as a growth factor and accelerate avian development.

\section{Úloha leptínu vo vývine prepelice japonskej}

Leptín, hormón produkovaný prevažne tukovým tkanivom, reguluje energetickú rovnováhu a taktiež ovplyvňuje embryonálny vývin a rast. V našej práci sme sledovali účinok leptínu, aplikovaného počas embryonálneho vývinu, na liahnivosṫ, postnatálny rast a vývin prepelice japonskej (Coturnix japonica). Do vaječného bielka sme v piatom dni embryonálneho vývinu injikovali $0,1 \mu \mathrm{g}$ a $1 \mu \mathrm{g}$ myšieho rekombinantného leptínu v $50 \mu \mathrm{l}$ tlmivého fosfátového pufru. Denne sme sledovali hmotnostné prírastky prepelíc, v 0., 2., 5., 7., 14., 21., 28., 35., 42., 49., a 56. dni sme zvieratá dekapitovali. Stanovovali sme koncentrácie trijódtyronínu $\left(\mathrm{T}_{3}\right)$ a testosterónu $\mathrm{v}$ plazme a obsah celkových tukov $\mathrm{v}$ plazme a v pečeni. Prepelice $\mathrm{z}$ experimentálnych skupín, do ktorých sme aplikovali leptín, sa liahli skôr a ich telesná hmotnost̉ bola počas celého sledovaného obdobia vyššia než u kontrolných zvierat $(p<0.05)$. Bezprostredne po vyliahnutí a pred dosiahnutím pohlavnej dospelosti sme pozorovali signifikantné zmeny v koncentráciách $\mathrm{T}_{3}$, celkových tukov a $\mathrm{v}$ telesnej hmotnosti. U leptínových skupín boli vyššie hodnoty testosterónu a vyššia znáška než u kontrolných skupín. Predpokladáme, že endokrinné osi vyvíjajúceho sa vtáčieho embrya sú ovplyvnitelné leptínom, a podanie tohoto hormónu počas embryonálneho života môže urýchlit embryonálny vývin vtákov.

Acknowledgements

This work was supported by a grant from the Slovak Grant Agency for Science VEGA (No.2/1015/2001).

\section{References}

AHIMA, R. S., DUSHA,Y. J., FLIER, S. N., PRABAKAN, D., FLIER, J. S. 1997: Leptin accelerates the onset of puberty in normal female mice. J Clin Invest 99: 391-395

AHIMA, R. S., PRABAKARAN, D., MANTZOROS, C., QU, D., LOWELL, B. B. 1996: Role of leptin in the neuroendocrine response to fasting. Nature 382: 250-252

ASHWELL, C. M., CZERWINSKI, S. M., BROCHT, D. M., McMURTRY, J. P. 1999: Hormonal regulation of leptin expression in broiler chickens. Am J Physiol 276: 226-232

BARASH, I. A., CHEUNG, C. C., WEIGLE, D. S., REN, H., KABIGTING, E. B., KUIJPER, J. L., CLIFTON, D. K. and STEINER, R. A. 1996: Leptin is a metabolic signal to the reproductive system. Endocrinology 137: $3144-$ 3147

CHEHAB, F. F., MOUNZIH, K., LU, R., LIM, M. E. 1997: Early onset of reproductive function in normal female mice treated with leptin. Science 275: 88-90

DOYON, C., DROUIN, G., TRUDEAU, V. L., MOON, T. W. 2001: Molecular evolution of leptin. Gen Comp Endocrinol 124: 188-198

FRIEDMAN, J. M., HALAAS, J. L. 1998: Leptin and the regulation of body weight in mammals. Nature 395: 736-770 FRIEDMAN-EINAT, M., BOSWELL, T., HOREV, G., SHARP, P. 1999: The chicken leptin gene has it been cloned? Gen Comp Endocrinol 115: 354-363

GONZALEZ, R. R., CABALLERO-CAMPO, P., JASPER, M., MERCADER, A., DEVOTO, L., PELLICER, A. SIMON, C. 2000: Leptin and leptin receptor are expressed in the human endometrium and endometrial leptin secretion is regulated by the human blastocyst. J Clin Endocrinol Metab 85: 4883-4888 
HOGGARD, N., HUNTER, L., DUNCAN, J., WILLIAMS, L., TRAYHURN, P. MERCER, J. 1997: Leptin and leptin receptor mRNA and protein expression in the murine fetus and placenta. PNAS 94: 11073-11078

LAMOŠOVÂ, D., ZEMAN, M. 2001: Effect of leptin and insulin on chick embryonic muscle cells and hepatocytes. Physiol Res 50: 183-189

LORD, G. M., MATARESE, G., HOWARD, J. K., BAKER, R. J., BLOOM, S. R., LECHIER, R. I. 1998: Leptin modulates the T-cell immune response and reverses starvation-induced immunosuppression. Nature 394: 897901

MASUZAKI, H., OGAWA, Y., SAGAWA, N., HOSODA, K., MATSUMOTO, T., MISE, M., NISHIMURA, H., YOSHIMASA, Y., TANAKA, I., MORI, T., NAKAO, K. 1997: Nonadipose tissue production of leptin: Leptin as a novel placenta-derived hormone in humans. Nat Med 3: 1029-1033

McMURTRY, J., ASHWELL, C., RICHARDS, M. 2000: Hormonal and developmental regulation of leptin gene expression in the chicken. In: Proceeding the 7th International Symposium on Avian Endocrinology, GUPTA $\mathrm{D}$ (ed), Varanasi, India

McNABB, F. M. A. 1987: Comparative thyroid development in precocial Japanese quail and altricial Ring doves. J Exp Zool Suppl 1: 281-290

REITMAN, M. L., BI, S., MARCUS-SAMUELS, B., GAVRILOVA, O. 2001: Leptin and its role in pregnancy and fetal development. Biocheml Soc 29: 68-72

STARCK, J.M., RICKLEFS, R. E. 1998: Avian growth rate data set. In: Avian growth and development. JM Starck and RE Ricklefs (Eds), Oxford University Press, New York, 381- 423

TANABE, K., OKUYA, S., TANIZAWA, Y., MATSUMOTO, A., OKA, Y. 1997: Leptin induces proliferation of pancreatic $\beta$ cell line MIN6 through activation of mitogen-activated protein kinase. Biochem Biophys Res Commun 241: 765-768

TAOUIS, M., CHEN, J. W., DAVIAUD, C., DUPONT, J., DEROUET, M., SIMON, J. 1998: Cloning the chicken leptin gene. Gene 208: 239-242

TSUCHIYA, T., SHIMIZU, H., HORIE, T. MORI, M. 1999: Expression of leptin receptor in lung: leptin as a growth factor. Eur J Pharmacol 365: 273-279

YU, W. H., KIMURA, M., WALCZEWSKA, A., KARANTH, S., Mc CANN, S. M. 1997: Role of leptin in hypothalamic-pituitary function. Proc. Natl. Acad. Sci. USA 94: 1025 